\title{
ADSORPTIVE REMOVAL OF AROMATIC COMPOUND BY MONTMORILLONITE: APPLICATION OF FACTORIAL DESIGN ANALYSIS
}

\author{
Feza GEYIKÇI ${ }^{1)}$ and Semra ÇORUH ${ }^{2) *}$ \\ 1) Ondokuz Mayls University, Chemical Engineering Department, Kurupelit, Samsun, Turkey, \\ e-mail:fezag@omu.edu.tr \\ 2) Ondokuz Mayls University, Environmental Engineering Department, Kurupelit, Samsun, Turkey \\ *Corresponding author's e-mail: semcoruh@omu.edu.tr
}

(Received March 2013, accepted July 2013)

\begin{abstract}
Phenolic compounds are common pollutants found particularly in the effluents from petroleum and petrochemical, coal conversion, and phenol producing industries. Due to their toxicity and carcinogenity, water and wastewater containing phenolic compounds must be treated before being used and discharged for receiving water bodies. There is a growing interest in using low-cost and commercially available materials for the adsorption of organic compounds. Clay minerals have great potential to remove phenols in water due to efficient sorbents which can be used as alternative adsorbents to replace the costly activated carbon. They are widely applied in many fields of adsorption technology including the removal of amines, metals, ketones, phosphates, chlorophyll, non-ionic contaminants, and organic pigments/dyes. Montmorillonitic smectites, $\left\{(\mathrm{Na}, \mathrm{Ca})_{0.33}(\mathrm{Al}, \mathrm{Mg})_{2}\left(\mathrm{Si}_{4} \mathrm{O}_{10}\right)-(\mathrm{OH})_{2} \cdot \mathrm{nH}_{2} \mathrm{O}\right\}$ are one of the natural clay minerals that have specific surface chemical properties. In this study, a factorial experimental design technique was used to investigate the adsorption of phenol from water solution on montmorillonite. Factorial design of experiments is employed to study the effect of three factors: $\mathrm{pH}(2.0$ and 8.0), montmorillonite dosage $(0.1$ and $1.0 \mathrm{~g} / \mathrm{L})$ and initial low and high concentration $(10$ and $100 \mathrm{mg} / \mathrm{L})$. The efficiency of phenol adsorption was determined after $60 \mathrm{~min}$ of treatment. Main effects and interaction effects of three factors were analyzed by using statistical techniques. A regression model was found to fit the experimental data very well. Through using the Student's $t$-test, analysis of variance, $F$-test and lack of fit to define most important process variables affecting the percentage phenol adsorption.
\end{abstract}

KEYWORDS: montmorillonite, factorial design analysis, phenol adsorption

\section{INTRODUCTION}

Phenol is one of major pollutant presenting in the wastewaters from several industrial activities such as coal mining, petrol refining, plastics, textiles, founding and steel and iron manufacture, pulp and paper manufacture and the tanning and finishing of leather. Typical phenol concentrations in these wastewaters range from 100 to $1000 \mathrm{mg} / \mathrm{L}$. It is very important to remove phenols and aromatic compounds from contaminated water before discharge into any natural water because of their toxicity to aquatic organism (Tor et al., 2009). The concentrations of phenol in industrial effluents are normally in a range of 2.8-6800 ppm which is much higher than the Lethal dose $\left(\mathrm{LD}_{50}\right)$ for aquatic lives $(\mathrm{Ng}$ et al., 2011). Phenol is toxic with a probable oral lethal dose to humans of $50-500 \mathrm{mg} / \mathrm{kg}$. Ecotoxicity in water $\left(\mathrm{LC}_{50}\right)$ is $125 \mathrm{mg} / 1$ for 24 hours (Environmental Protection Division, 2002) .

As a class of organics, phenols are similar in structure to the more common herbicides and insecticides in that they are resistant to biodegradation. Some phenols are very soluble in water and their presence in water supplies are noticed due to the taste and odor. The odor threshold for phenol is $0.04 \mathrm{ppm}$ according to the regulations of Environmental Protection Agency (EPA). The utilization of phenol-contaminated water causes protein degeneration, tissue erosion, and paralysis of the central nervous system and also damages the kidney, liver and pancreas in human body (Senturk et al., 2009). According to the recommendation of World Health Organization (WHO), the permissible concentration of phenolic contents in potable waters is $1.0 \mu \mathrm{g} / \mathrm{L}$ and the regulations by the Environmental Protection Agency (EPA), call for lowering phenol content in wastewaters less than $1.0 \mathrm{mg} / \mathrm{L}$ (Bevilaqua et al., 2002; Radhika and Palanivelu, 2006; Senturk et al., 2009).

Conventional processes for removal of phenols from industrial wastewaters include exctraction, precipitation, ion exchange, adsorption, electrochemical techniques, irradiation etc. Among these methods and technologies, adsorption is still the most attractive and widely used. Conventional adsorption experiments by changing only one or two factors at one time are laborious, costing time, and consuming materials. It is also impossible to detect the frequent interactions which occur between two or more factors. The evaluation of the best adsorption conditions of organic matter in different material has been made by several researchers by using a factorial design technique (Stanisavljevic et al, 2004; Manojlovic et al., 2007; Rathinam et al., 2011; An et al., 2012; Zeng et al., 
Table 1 The chemical composition of montmorillonite.

\begin{tabular}{lllllllllllll}
\hline Constituent & $\mathrm{SiO}_{2}$ & $\mathrm{Al}_{2} \mathrm{O}_{3}$ & $\mathrm{Fe}_{2} \mathrm{O}_{3}$ & $\mathrm{MgO}$ & $\mathrm{K}_{2} \mathrm{O}$ & $\mathrm{CaO}$ & $\mathrm{TiO}_{2}$ & $\mathrm{NaO}_{2}$ & $\mathrm{MnO}$ & $\mathrm{Cr}_{2} \mathrm{O}_{3}$ & $\mathrm{P}_{2} \mathrm{O}_{5}$ & $\mathrm{LOI}^{\mathrm{a}}$ \\
\hline $\mathrm{w} \%$ & 57.8 & 17.7 & 7.9 & 2.4 & 1.6 & 1.5 & 0.8 & 0.5 & 0.3 & 0.1 & $<0.1$ & 9.05 \\
\hline
\end{tabular}

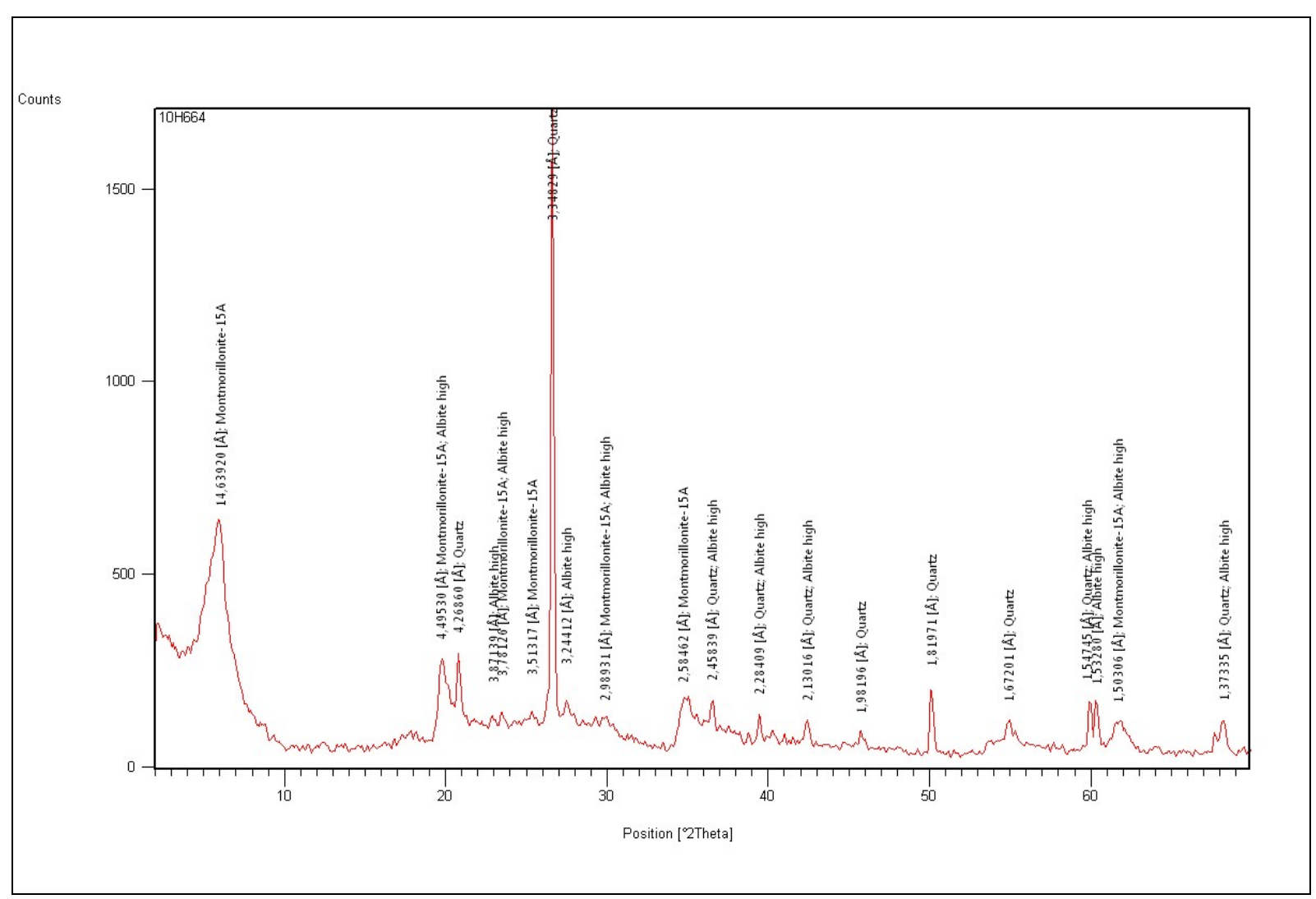

Fig. 1 XRD pattern of montmorillonite.

2012). The study of the factors affecting the adsorption process was made by a two-level factorial design. A number of factors influencing the process such as $\mathrm{pH}$, adsorbent dosage and initial concentration of phenol in the solution were studied.

\section{MATERIALS AND METHODS \\ MATERIALS}

The montmorillonite, used in the experiments was supplied from Bafra in Turkey. It contains various amounts of smectite, quartz, feldspar group and amorphous material, which is a kind of montmorillonite. The chemical composition of the montmorillonite was given in Table 1. Major elements of montmorillonite were determined by X-Ray Fluorescence (XRF) spectrometer. The formation of a new structure was determined by the peak internal between $2.5^{\circ}-70^{\circ}$ in the X-Ray Diffraction (XRD) pattern montmorillonite (Fig. 1). The specific Brunauer-Emmett-Teller (BET) surface area of montmorillonite was measured with nitrogen as $73.916 \mathrm{~m}^{2} / \mathrm{g}$.

\section{METHOD}

Natural montmorillonite, grey in color was used as an adsorbent. It was dried, and then washed with distilled water several times to remove any dust and other water-soluble impurities. The washed sample was dried at $105{ }^{\circ} \mathrm{C}$ in an oven before using in the adsorption studies. All adsorption experiments were carried out with the batch method. Adsorption properties of montmorillonite were evaluated by depending on different adsorption conditions such as different $\mathrm{pH}$, adsorbent dosage and initial phenol concentrations. The concentrations of phenol were determined by using UV/Vis Spectrophotometer at $\lambda=$ $500 \mathrm{~nm}$ according to the 4-aminoantipyrene method (APHA-AWWA, 1992). The adsorption percentage of phenol was calculated by the difference of initial concentration using the equation expressed as follow:

$R=\frac{C_{o}-C_{e}}{C_{o}} \times 100$

where $C_{o}$ is the initial concentration of phenol solution $(\mathrm{mg} / \mathrm{L}), C_{e}$ is the equilibrium concentration of the 
Table 2 Factors and levels used in the factorial design.

\begin{tabular}{lccc}
\hline Factor & Coded Symbol & Low Level $(-1)$ & High Level $(+1)$ \\
\hline $\mathrm{pH}$ & $A$ & 2 & 8 \\
Adsorbent Dosage $(\mathrm{g} / \mathrm{L})$ & $B$ & 0.1 & 1 \\
Initial Concentration $(\mathrm{mg} / \mathrm{L})$ & $C$ & 10 & 100 \\
\hline
\end{tabular}

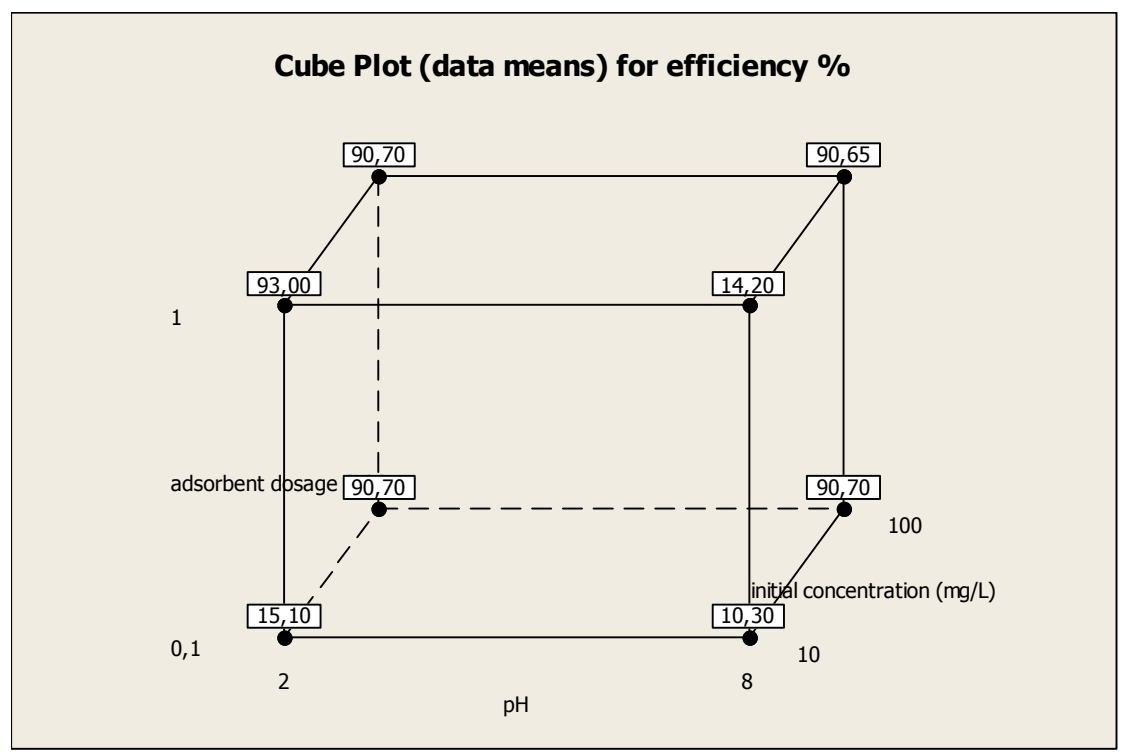

Fig. 2 Cube plots for efficiency (\%).

phenol solution $(\mathrm{mg} / \mathrm{L})$, and $\mathrm{R}$ is the retention of phenol in $\%$ of the added amount.

\section{FACTORIAL EXPERIMENTAL DESIGN}

Factorial design is employed to reduce the total number of experiments in order to achieve the best overall optimization of the system. It was used to reduce the number of experiments, time, overall process cost and to obtain better response (Lima et al., 2011). The design determines that factors have important effects on a response as well as how the effect of one factor varies with the level of the other factors. The number of experimental runs at $b$ levels is $\mathrm{b}^{\mathrm{k}}$, where $\mathrm{k}$ is the number of factors (Navidi, 2008). Today, the most widely used kind of experimental design, to estimate main effects as well as interaction effects, is the $2^{\mathrm{p}}$ factorial design in which each variable is investigated at two levels (Kavak, 2009).

The high and low levels defined for the $2^{3}$ factorial designs were listed in Table 2 . The low and high levels for the factors were selected according to some preliminary experiments. The order in which the experiments were made was randomized to avoid systematic errors. The results were analyzed with the Minitab 16 software, and the main effects and interactions between factors were determined. The $2^{3}$ factorial design cubical diagrams with high and low three factors, $\mathrm{pH}$ adsorbent dosage and initial concentration are shown in Figure 2. Figure 2 illustrates the meaning of the experimental results for the respective low and high levels of adsorbent dosage, initial concentration and $\mathrm{pH}$.

\section{RESULT AND DISCUSSION}

The factorial design matrix and adsorption efficiency $(\%)$ measured in each factorial experiment is shown in Table 3, with the low $(-1)$ and high $(+1)$ levels as specified in Table 2.

Factors that influence the adsorbed quantity of phenol adsorbed onto montmorillonite were evaluated

Table 3 Design matrix and the results of the $2^{3}$ full factorial design.

\begin{tabular}{ccccc}
\hline Run No & A & B & C & $\begin{array}{c}\text { Average (adsorption } \\
\text { efficiency \%) }\end{array}$ \\
\hline 1 & -1 & -1 & -1 & 15.1 \\
2 & +1 & -1 & -1 & 10.3 \\
3 & -1 & +1 & -1 & 93.0 \\
4 & +1 & +1 & -1 & 14.2 \\
5 & -1 & -1 & +1 & 90.7 \\
6 & +1 & -1 & +1 & 90.7 \\
7 & -1 & +1 & +1 & 90.7 \\
8 & +1 & +1 & +1 & 90.65 \\
\hline
\end{tabular}

A: $\mathrm{pH} ; \quad$ B: Adsorbent Dosage (g/L);

$\mathrm{C}$ : Initial Concentration $(\mathrm{mg} / \mathrm{L})$ 
Table 4 Estimated effects and coefficients.

\begin{tabular}{|c|c|c|c|c|c|}
\hline \multicolumn{6}{|c|}{ Estimated Effects and Coefficients for Efficiency $(\%)$ (coded units) } \\
\hline Term & Effect & Coef & SE Coef & $\mathbf{T}$ & $\mathbf{P}$ \\
\hline \multicolumn{2}{|l|}{ Constant } & 75.29 & 0.1432 & 525.64 & 0.000 \\
\hline $\mathrm{pH}$ & -43.94 & -21.97 & 0.1432 & -153.38 & 0.000 \\
\hline Dosage & 1.46 & 0.73 & 0.1432 & 5.10 & 0.001 \\
\hline Concentration & 36.05 & 18.03 & 0.1432 & 125.85 & 0.000 \\
\hline $\mathrm{pH} *$ Dosage & 5.61 & 2.81 & 0.1432 & 19.59 & 0.000 \\
\hline $\mathrm{pH} *$ Concentration & 38.24 & 19.12 & 0.1432 & 133.48 & 0.000 \\
\hline Dosage*Concentration & -3.96 & -1.98 & 0.1432 & -13.84 & 0.000 \\
\hline $\mathrm{pH}^{*}$ Dosage*Concentration & -3.11 & -1.56 & 0.1432 & -10.87 & 0.000 \\
\hline \multicolumn{6}{|c|}{$\mathrm{S}=0.572926 \quad \mathrm{PRESS}=10.5038$} \\
\hline \multicolumn{6}{|c|}{$\mathrm{R}-\mathrm{Sq}=99.99 \% \quad \mathrm{R}-\mathrm{Sq}(\mathrm{pred})=99.94 \% \quad \mathrm{R}-\mathrm{Sq}(\mathrm{adj})=99.97 \%$} \\
\hline
\end{tabular}

Table 5 Analysis of variance.

\begin{tabular}{lcrrrrr}
\hline Analysis of Variance for Efficiency(\%) $($ coded units) & & & \\
\hline Source & DF & Seq SS & Adj SS & Adj MS & F & P \\
\hline Main Effects & 3 & 12929.8 & 12929.8 & 4309.92 & 13130.25 & 0.000 \\
pH & 1 & 7722.5 & 7722.5 & 7722.46 & 23526.59 & 0.000 \\
Dosage & 1 & 8.5 & 8.5 & 8.54 & 26.02 & 0.001 \\
Concentration & 1 & 5198.8 & 5198.8 & 5198.77 & 15838.14 & 0.000 \\
2-Way Interactions & 3 & 6036.8 & 6036.8 & 2012.28 & 6130.44 & 0.000 \\
pH*Dosage & 1 & 125.9 & 125.9 & 125.94 & 383.69 & 0.000 \\
pH*Concentration & 1 & 5848.0 & 5848.0 & 5848.04 & 17816.16 & 0.000 \\
Dosage*Concentration & 1 & 62.8 & 62.8 & 62.85 & 191.46 & 0.000 \\
3-Way Interactions & 1 & 38.8 & 38.8 & 38.78 & 118.15 & 0.000 \\
pH*Dosage*Concentration & 1 & 38.8 & 38.8 & 38.78 & 118.15 & 0.000 \\
Residual Error & 8 & 2.6 & 2.6 & 0.33 & & \\
Pure Error & 8 & 2.6 & 2.6 & 0.33 & & \\
Total & 15 & 19008.0 & & & &
\end{tabular}

by using factorial plots: main effect, interaction effect. ANOVA and P-value significant levels were used to check the significance of the effect on adsorption efficiency $(\%)$.

The results were displayed in Tables 4 and 5 . Main, interaction effect, coefficients of the model, standard deviation of each coefficient, and probability for the full $2^{3}$ factorial designs were presented in Table 4. The significance of the regression coefficients was determined by applying a Student's t-test. All effects were significant with $95 \%$ confidence level. In addition, the model presented an adjusted square correlation coefficient $R^{2}$ (adj) of $99.97 \%$, fitting the statistical model quite well. In this way, the phenol uptake by montmorillonite could be expressed using the following equation:

$$
\begin{aligned}
& R(\%)=75.297-21.97 \cdot p H-0.73 \cdot \text { Dosage }+ \\
& +18.03 \cdot \text { Concentration }+ \\
& +2.81 \cdot p H^{*} \text { Dosage }+19.12 \cdot p H * \text { Concentration }- \\
& -1.98 \cdot \text { Dosage } * \text { Concentration }- \\
& -1.56 \cdot p H^{*} \text { Dosage } * \text { Concentration }
\end{aligned}
$$

Table 5 shows the sum of squares being used to estimate the factors effect and the $F$-ratios, which are defined as the ratio of respective mean-square-effect to the men-square-error. The significance of these effects was evaluated using the t-test, and had a significance level of $5 \%$; i.e., with a confidence level of $95 \%$. The $R$-squared statistic indicated that the firstorder model explained $99.94 \%$ of R's variability to the rejection of null hypothesis, it appears that the main effect of each factor and the interaction effects were statistically significant: $\mathrm{P}<0.05$ (Abdel-Ghani et al., 2009). The results revealed that the studied factors $(\mathrm{A}, \mathrm{B}$ and $\mathrm{C})$, their 2-way interaction $(\mathrm{AB}, \mathrm{AC}$ and $\mathrm{BC})$ and 3-way interaction (ABC) were statistically significant to $R(\%)$.

The main effects represent deviations of the average between high and low levels for each one of them. When the effect of a factor is positive, adsorption efficiency increase as the factor is changed from low to high levels. In contrast, if the effects are negative, a reduction in adsorption efficiency occurs for high level of the same factor (Ponnusamiet al., 2007; Bingöl et al., 2010).

The main effects of each parameter on the phenol adsorption are shown in Figure 3. The main 


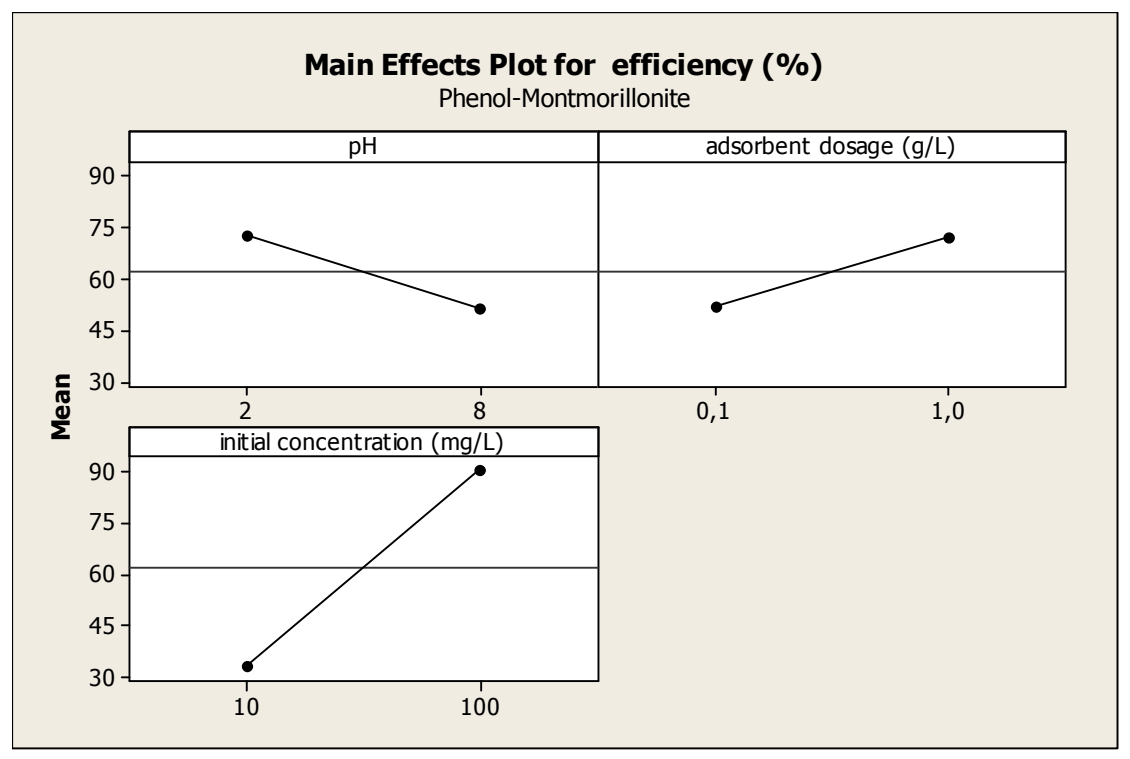

Fig. 3 Main effect plots for efficiency (\%).

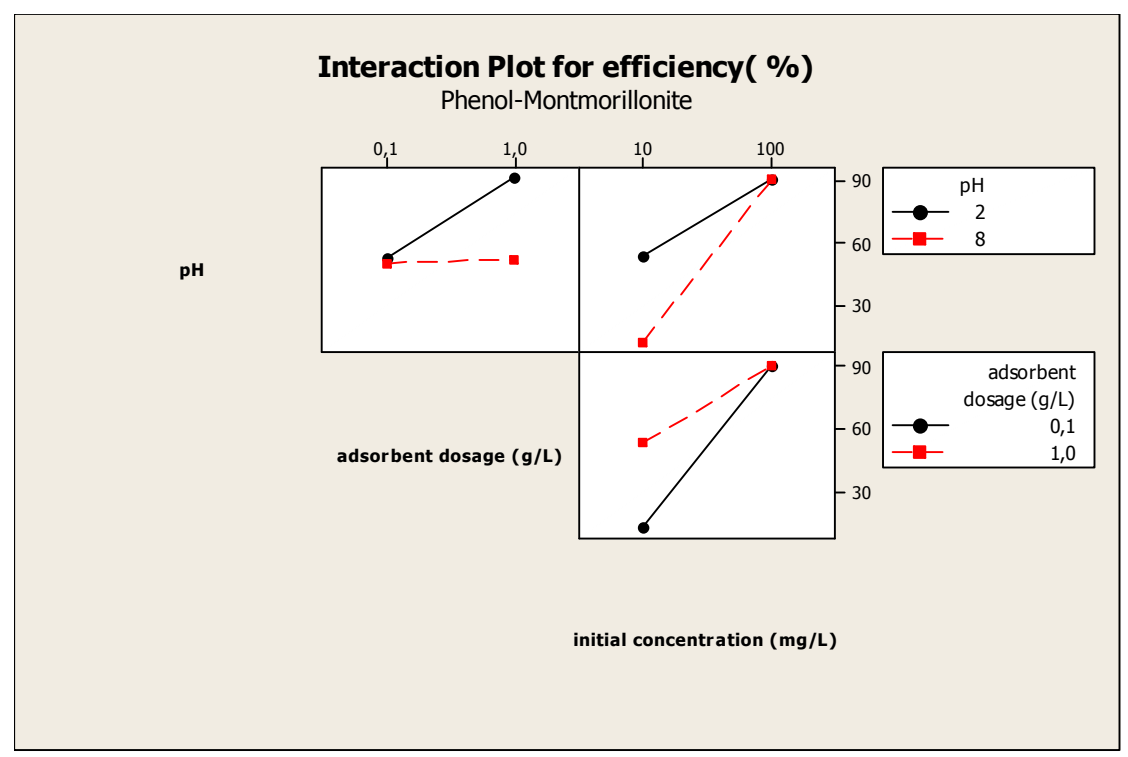

Fig. 4 Interaction effect plots for efficiency (\%).

effects plots were generated to represent the results of regression analysis. It shows only the factors that were significant at the $95 \%$ confidence interval. Figure 3. shows that significance effect upon efficiency have the control factors: $\mathrm{pH}$, dosage and initial concentration. In Figure 3, the parameter $\mathrm{pH}$ that has a negative influence upon adsorption process efficiency can be seen. The dosage and the initial concentration have strong positive influences upon adsorption process efficiency. These conclusions are in a strong correlation with the results obtained from the adsorption studies.

The interaction effects of each parameter on the phenol adsorption are shown in Figure 4. The interactions between the lines in Figure 4, are not parallel. A strong deviation from the parallelism put in evidence a strong interaction among control factors Figure 4 shows following significance interaction: $\mathrm{pH}$ and dosage, $\mathrm{pH}$ and initial concentration for adsorption efficiency, respectively. According to the Seq SS values, interaction of $\mathrm{pH}$ and initial concentration is the most significantly interaction. The other important interaction is $\mathrm{pH}$ and dosage. That means when the conclusion must be drawn very carefully, because the interaction can mask the main effects of the control factors.

These screening designs have made a mathematical model, a linear one, for adsorption efficiency. 


\section{CONCLUSIONS}

The present investigation shows that montmorillonite is an effective adsorbent for adsorption of phenol. The effects of process parameters such as $\mathrm{pH}$, montmorillonite dosage and initial concentration were studied. The most significant interaction was found to be $\mathrm{pH}$-initial concentration. Then $\mathrm{pH}$-montmorillonite dosage of phenol interaction, montmorillonite dosageinitial concentration of phenol interaction and $\mathrm{pH}-$ initial concentration of phenol interaction were also found highly significant. The statistical design of the experiments combined with techniques of regression was applied in optimizing the conditions of maximum adsorption of the phenol onto montmorillonite. According to the Seq SS values, $\mathrm{pH}$ is the most significant factor. ANOVA indicated that the most considerable factor was $\mathrm{pH}$ for phenol. Individual, two and three ways interactions were also significant. In this study, $F$-test presents the $F$ statistic for testing the null hypothesis that the main effects and the twoway, and three-way interactions are equal to zero, respectively. " $P$ '" presents the $P$-value for the $F$ - test. The small $P$-values $(<0.05)$ mean that not all the main effects and interactions are zero at the $5 \%$ significance level. In other words, there is reasonably strong evidence that at least some of the main effects and interactions are not equal to zero. Finally, it can be concluded that experimental design studies can be used for adsorption investigations as well as the others by reducing the total number of experiments.

\section{REFERENCES}

Abdel-Ghani, N.T., Hegazy, A.K., El-Chaghaby, G.A. and Lima, E.C.: 2009, Factorial experimental design for biosorption of iron and zinc using Typha domingensis phytomass. Desalination 249, 343-347. DOI: $10.1016 /$ j.desal.2009.02.065

An, F., Du, R., Wang, X., Wan, M., Dai, X. and Gao, J.: 2012, Adsorption of phenolic compounds from aqueous solution using salicylic acid type adsorbent. Journal of Hazardous Materials, 201-202, 74-81. DOI: 10.1016/j.jhazmat.2011.11.037

APHA, AWWA, and WPCF: 1992, Standart Methods for the Examination of Water and Wastewater, 18 th ed. Washington.

Bevilaqua, J.V., Cammarota, M.C., Freire, D.M.G. and Sant'Anna, G.L.: 2002, Phenol removal through combined biological and enzymatic treatments, Brazilian Journal of Chemical Engineering, 19 (2), 151-158. DOI: 10.1590/S0104-66322002000200010

Bingol, D., Tekin, N. and Alkan, M.: 2010, Brilliant yellow dye adsorption onto sepiolite using a full factorial design, Applied Clay Science, 50, 315-321. DOI: $10.1016 /$ j.clay.2010.08.015

Environmental Protection Division, Technical Report, Water Quality Guidelines for Phenols, 2002.
Kavak, D.: 2009, Removal of boron from aqueous solutions by batch adsorption on calcined alunite using experimental design, J. Hazard. Mater., 163, 308-314. DOI: 10.1016/j.jhazmat.2008.06.093

Lima, L.S., Araujo, M.D.M., Quináia, S.P., Migliorine, D.W. and Garcia, J.R.: 2011, Adsorption modeling of $\mathrm{Cr}, \mathrm{Cd}$, and $\mathrm{u}$ on activated carbon of different origins by using fractional factorial design, Chem. Eng. J., 166, 881-889. DOI: 10.1016/j.cej.2010.11062

Manojlovic, D., Ostojic, D.R., Obradovic, B.M., Kuraica, N.M., Krsmanovic, V.D. and Puric, J.: 2007, Removal of phenol and chlorophenols from water by new ozone generator, Desalination, 213, 116-122. DOI: $10.1016 / j$.desal.2006.05.059

Navidi, W.: 2008, Statistics for engineers and scientist, New York: McGraw-Hill Companies, Inc.

Ng, Y.S., Jayakumar, N.S. and Hashim, M.A.: 2011, Behavior of hydrophobic ionic liquids as liquid membranes on phenol removal: Experimental study and optimization, Desalination, 278, 250-258. DOI: $10.1016 /$ j.desal.2011.05.047

Ponnusami, V., Krithika, V., Madhuram, R. and Srivastava, S.N.: Biosorption of reactive dye using acid-traeted rice husk: Factorial design design analysis, Journal of Hazardous Materials, 142, 397-403. DOI: $10.1016 /$ j.jhazmat.2006.08.040

Radhika, M. and Palanivelu, K.: 2006, Adsorptive removal of chlorophenols from aqueous solution by low cost adsorbent- Kinetics and isotherm analysis, J. Hazard. Mater. 138 (1), 116124.

DOI: $10.1016 /$ j.jhazmat.2006.05.045

Rathinam, A., Rao, J.R. and Nair, B.U.: 2011, Adsorption of phenol onto activated carbon from seaweed: Determination of the optimal experimental parameters using factorial design. Journal of the Taiwan Institute of Chemical Engineers, 42-6, 952-956. DOI: $10.1016 /$ j.jtice.2011.04.003

Stanisavljevic, M. and Nedic, L.: 2004, Removal of phenol from industrial wastewaters by horseradish peroxidase, Working and Living Environmental Protection, 2 (4), 345-349.

Senturk, H.B., Ozdes, D., Gundogdu, A., Duran, C. and Soylak, M.: 2009, Removal of phenol from aqueous solutions by adsorption onto organomodified Tirebolu bentonite: Equilibrium, kinetic and thermodynamic study. Journal of Hazardous Materials, 172, 353-362. DOI: 10.1016/j.jhazmat.2009.07.019

Tor, A., Cengeloglu, Y. and Ersoz, M.: 2009, Increasing the phenol adsorption capacity of neutralized red mud by application of acid activation procedure. Desalination, 242, 19-28. DOI: 10.1016/j.desal.2008.03.028

Zeng, Z., Zou, H., Li, X., Sun, B., Chen, J. and Sbal, L.: 2012, Ozonation of acidic phenol wastewater with $\mathrm{O}_{3} / \mathrm{Fe}(\mathrm{II})$ in a rotating packed bed reactor: Optimization by response surfacemethodology. Chemical Engineering and Processing: Process Intensification, 60, 1-8. DOI: $10.1016 /$ j.cep.2012.06.006 